\title{
The growth and reproductive biology of the coral gall crab, Hapalocarcinus marsupialis Stimpson, 1859 (Crustacea: Cryptochiridae) from Gulf of Aqaba, Red Sea, Egypt
}

Khaled A. El-Damhougy ${ }^{1}$, El-Sayed S. E. Salem², Maged M. A. Fouda ${ }^{3 *}$ and Montaser A. M. M. Al-Hammady ${ }^{4}$

\begin{abstract}
Background: Gall crabs were described 150 years ago, but little is known about their biology, ecology, and taxonomy. Studying the breeding season can facilitate the understanding of the adaptive strategies and reproductive potential of gall crab and its relationship with the environment and other species.

Results: Growth and reproductive biology of the coral gall crab, Hapalocarcinus marsupialis, were studied at Gulf of Aqaba, Red Sea, Egypt. A total of 209 specimens were collected from different reef depths during 2014. Relationship between carapace width (CW) and total body wet weight (W) was represented as log W $=0.190+2.87 \log$ CW. Growth generally shows negative allometric pattern. While the relation between $\mathrm{CW}$ and $\mathrm{CL}$ is represented by log $\mathrm{CL}=0.019+1.009 \log \mathrm{CW}$. This relation is linear and shows an isometric regression coefficient. The overall value for " $\mathrm{Kn}$ " is varied from 0.8 to 1.24 , with an average of $1.11 \pm 0.13$, and denotes fitness for females. $H$. marsupialis shows clear sexual dimorphism and has lengthy definite breeding season characterized by carrying eggs throughout the year. The incubated eggs are semi spherical in shape, with diameter ranges according to maturity stages between 10 and $50 \mu \mathrm{m}$. The color of incubated eggs is also varied according to the developmental stage. Most females attain sexual maturity between 2.0 and $2.49 \mathrm{~mm} \mathrm{CW}$. Juveniles were recorded during year except the months of January and October. Fecundity varied from 10 to 740 eggs, with an average of $230 \pm 173$ eggs/female, showing linear relation with carapace width. Significant relationship between carapace width and fecundity was represented by $\log F=0.22+2.39 \log$ CW.

Conclusion: The present study emphasized the reproductive biology of $\mathrm{H}$. marsupialis and explained the size structure, sexual dimorphism, breeding season, fecundity, size at first maturity, and juvenile's recruitments in the three selected sites Dahab, Nuweiba and Taba along the Gulf of Aqaba.
\end{abstract}

Keywords: Hapalocarcinus marsupialis, Growth, Sex dimorphism, Spawning season, Fecundity

\footnotetext{
* Correspondence: aaaa_maged2000@yahoo.com

${ }^{3}$ Faculty of Science, Al-Azhar University, Assuit, Egypt

Full list of author information is available at the end of the article
} 


\section{Background}

Brachyuran decapods are abundant among branching corals (Patton, 1974; Castro, 1976) especially in the Acroporidae and Pocilloporidae families (Abele, 1984). The coral gall crab, Hapalocarcinus marsupialis, was described for the first time living on corals (Stimpson, 1859). The ability of the crab to initiate gall development in its host coral was documented by Verrill (1867). $H$. marsupialis is widely distributed on the western shores of the Indian Ocean from the Red Sea to South Africa and extending through the tropical Indian and Pacific Oceans to the western coasts of central and south America (Kropp, 1990). Kotb and Hartnoll (2002) studied the reproduction of gall crab $H$. marsupialis in Stylophora pistillata and divided the coral galls into five stages, where the late stages contained larger and matured crabs and had a high crab production of ovigerous females. The physiological state of the gall crabs declines the growth rates and may increase mortality due to feed reduction or reproduction diversion (Hartnoll, 2006).

Reproductive periods for most brachyuran crabs can be estimated by gonadal development and by the ratio of ovigerous females throughout the year (Pillay \& Nair, 1971; Murai, Goshima, \& Henmy, 1987; Mouton JR \& Felder, 1995; Rodríguez, Drake, \& Arias, 1997; Chacur \& Negreiros-Fransozo, 2001; Flores, Saraiva, \& Paula, 2002; Negreiros-Fransozo, Fransozo, \& Bertini, 2002; Colpo \& Negreiros-Fransozo, 2003). The size at sexual maturity, based on external morphological features, can sometimes be misestimated when the curves for immature and mature specimens overlap (Somerton, 1980a, 1980b). In some species, morphological sexual maturity does not coincide with physiological sexual maturity (Conan \& Comeau, 1986; Choy, 1988; and FontellesFilho, 1989). The sexual maturity is related to the presence of mature gonads (producing gametes). Thus, to estimate the size at first maturation of a brachyuran, the degree of gonad development beyond the external morphological features should be considered (Watson, 1970; Brown \& Powell, 1972).

Males look free-living may move from one colony to another to mate or share a gall with a female (Castro, 1976; Warner, 1977; McCain \& Coles, 1979; and Vehof, Van der Meij, Türkay, \& Becker, 2014). Cryptochirid female crabs inhabit cavities for breeding in their entire lives. They have an allometric growth of their abdomen that forms a brood pouch under the cephalothorax. This feature is a synapomorphic character of the Cryptochiridae family that can be found among female pea crabs (family Pinnotheridae; Becker, 2010). Brachyuran crabs diversified shape to maximize egg production and offspring survivorship (López-Greco, Hernandez, Bolanos, Rodriguez, \& Hernandez, 2000). The present study aims to study reproductive biology of $H$. marsupialis, with emphasis on size structure, sexual dimorphism, breeding season, fecundity, size at first maturity, and juvenile recruitments in the three selected sites, Dahab, Nuweiba, and Taba along the Gulf of Aqaba.

\section{Methods}

A total of 209 specimens of gall crab $H$. marsupialis (165 females, 42 juveniles, and 2 males) were collected from different depths ranging from 0.5 to $3 \mathrm{~m}$ (the reef flat, reef edge, and reef slope) at three widely geographically separated sites along the Gulf of Aqaba. The sites

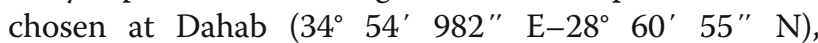
Nuweiba (34 64' 396" E-28 88' 119" N), and Taba (34 83' $057^{\prime \prime}$ E-29 42' 189" N) (Fig. 1).

The period of this study extended from January to December 2014. Female crabs were observed within the branches of stony corals Stylophora pistillata (family Pocilloporidae) at the shoreward side of reef flat, reef edge, and reef slope, while a fewer galls were observed at the seaward side of reef flat. Specimens of galls were randomly collected by using long-nose pliers to break off the branches with galls at their ends, without damaging coral colonies. Samples were immediately preserved in $10 \%$ formalin solution mixed with $5 \%$ alcohol and 5\% glycerol and kept in labeled plastic containers provided with date, site of collection, and coral species (Kotb \& Hartnoll, 2002). At the laboratory, examination and measurements were taken as soon as possible to limit changes in color of the crab or its body contents.

The collected specimens were identified to the species level according to Serene (1962, 1966), Kropp (1990), and Wei, Hwang, Tsai, and Fang (2006). The total body wet weight was taken to the nearest $0.01 \mathrm{~g}$ using an electric balance with accuracy of $0.01 \mathrm{~g}$ after blotting excess water with absorbent tissues. The carapace length (CL) and carapace width $(\mathrm{CW})$ were measured to the nearest $10 \mu \mathrm{m}$ using an eyepiece micrometer according to Kotb and Hartnoll (2002).

The relationships between carapace width $(\mathrm{CW})$ and total body weight (W) were calculated according to the following equation (Hile, 1936; Bagenal \& Tesch, 1978):

$$
Y=a \pm b x
$$

where $Y$ =body weight in milligrams, $X=$ carapace width in millimeters, $a=$ constant and equal to the intercept of the straight line with $Y$-axis; and $b=$ the coefficient of allometry. The method of least squares was used, and the coefficients (a) and (b) were calculated by plotting $\log Y$ against $\log X$ according to Hile (1936); Bagenal and Tesch (1978), and Le Cren (1951) where $\log Y=\log a \pm b \log X$. 


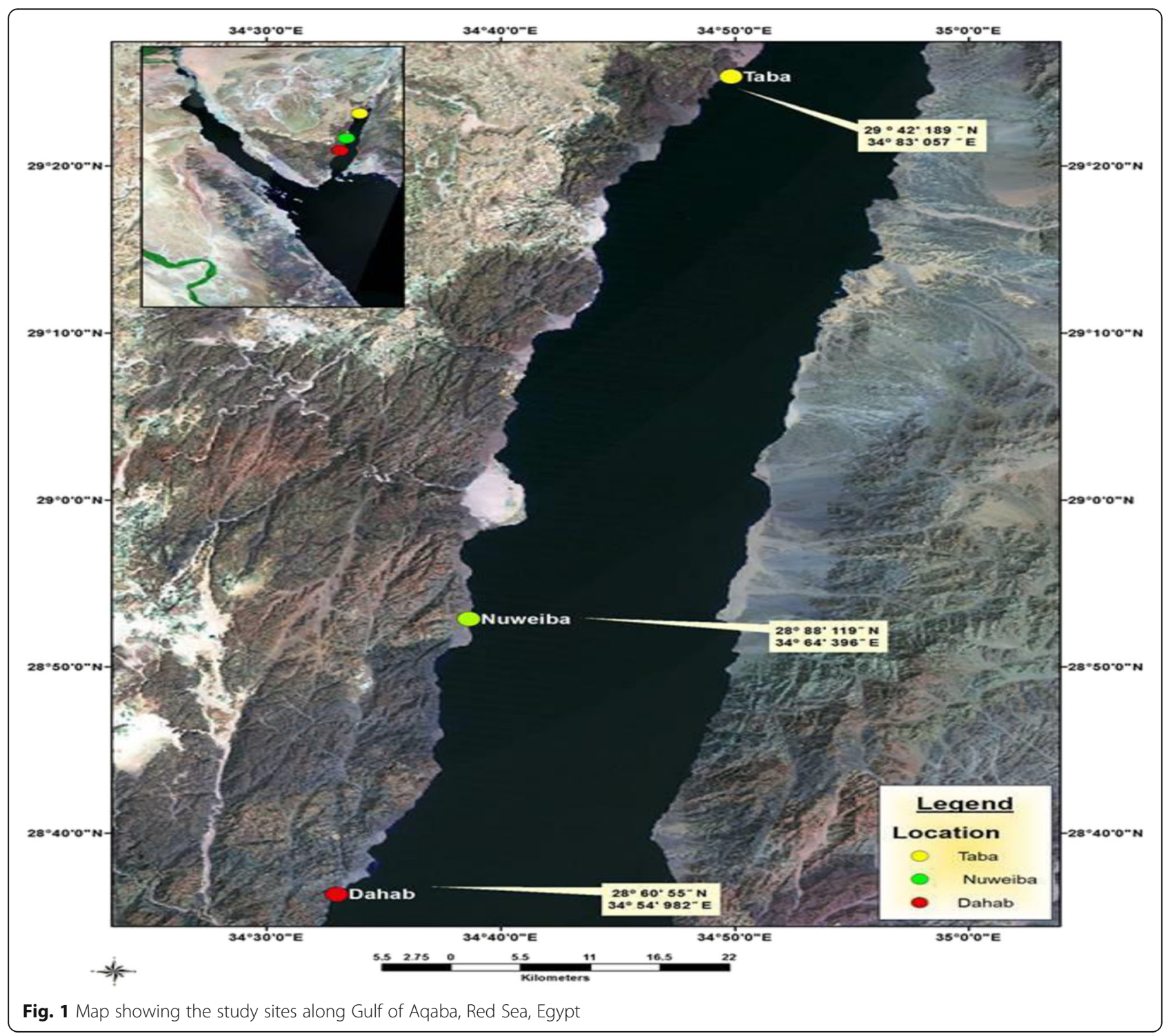

The well-being or relative condition factor " $k n$ " was calculated according the following formula: $\mathrm{kn}=W / W$ (Hile, 1936; Bagenal \& Tesch, 1978)

where $W=$ observed weight and $W^{\prime}=$ calculated weight from the width-weight relationship.

Eggs were carefully removed from the pleopods and counted under the stereomicroscope (Choy, 1985). Egg diameters were measured to the nearest micrometer $(\mu \mathrm{m})$ using Stereo-binocular microscope (PZO Warsaw) provided with graduated screen. The incidence of ovigerous females was noticed and used to determine the breeding season. The size of incubated eggs was measured at various developmental stages. The fecundity was calculated by counting incubated eggs according to Subramoniam (1982). The relationship between the egg number or absolute fecundity and female carapace width was calculated according to the following formula (Haynes, Karinen, Watson, \& Hopson, 1976):

$$
\log F=\log a \pm b \log \mathrm{CW}
$$

where $F=$ absolute fecundity and $\mathrm{CW}=$ female carapace width.

\section{Results}

\section{Morphometric relationships}

A total of 165 female specimens of $H$. marsupialis were used for studying the relationship between crab carapace width $(\mathrm{CW})$ and total body wet weight (W). Carapace width varied from 2.5 to $5.9 \mathrm{~mm}$, and crab wet weight ranged from 6 to $230 \mathrm{mg}$. The relationship between carapace width and body weight was represented by the following equation: 
$\log W=0.190+2.87 \log \mathrm{CW}$.

It is a curve linear relation with a high correlation coefficient $(r=0.98)$ and negative allometric regression coefficient $(b=2.87)$ with an intercept of $Y$-axis " $a$ " $=0.190$ (Table 1, Fig. 2). The value of " $b$ " denotes the fast increase in carapace width than body weight.

On the other hand, the relationship between carapace width $(\mathrm{CW})$ and carapace length $(\mathrm{CL})$ of $H$. marsupialis was calculated and represented (Fig. 3) by the following equation: $\log \mathrm{CL}=0.019+1.009 \log \mathrm{CW}(r=0.91)$.

This relation is linear and shows an isometric regression coefficient $(b=1.0096)$ (slope $=1.0, P<0.001)$; the carapace is becoming relatively wider and shorter with increasing size, the intercept of $Y$-axis "a" $=0.019$, and high correlation coefficient " $r$ " $=0.91$. Highly significant difference was found between the slopes of this relationship.

The results of relative condition factor "Kn" for different size classes of the females of $H$. marsupialis are given in Table 1 and represented in Fig. 4. The overall value for " $\mathrm{Kn}$ " is varied from 0.8 to 1.24 , with an average of $1.11 \pm 0.13$, and denotes fitness for females.

\section{Reproduction}

\section{Sexual dimorphism}

Morphologically, abdominal appendages are the main sex character for rapid differentiation between mature males and females of $H$. marsupialis. Mature males have relatively tapering abdomen provided with two unequal pairs of uniramus pleopods. On contrast, female's abdomen is more flattened, semicircular, provided with four biramous pleopods, usually fringed with entangled setae in maturing females, particularly during spawning season.

\section{Spawning season}

The spawning season of $H$. marsupialis was determined by the appearance of ovigorous females carrying clutches of fertilized eggs on their pleopods. $H$. marsupialis has

Table 1 The carapace width-body weight relationship and relative condition factor of H. marsupialis females from Gulf of Aqaba, Red Sea, Egypt

\begin{tabular}{|c|c|c|c|}
\hline \multirow{2}{*}{$\begin{array}{l}\text { Items } \\
\text { Size class } \\
(\mathrm{mm})\end{array}$} & \multicolumn{2}{|c|}{ Mean weight (mg) } & \multirow{2}{*}{$\begin{array}{l}\text { Relative } \\
\text { condition } \\
\text { factor " } k n \text { " }\end{array}$} \\
\hline & Observed & Calculated & \\
\hline $2.5-2.9$ & 0.95 & 1.16 & 0.8 \\
\hline $3-3.4$ & 1.57 & 1.34 & 1.17 \\
\hline $3.5-3.9$ & 1.85 & 1.49 & 1.24 \\
\hline $4-4.4$ & 1.89 & 1.62 & 1.16 \\
\hline $4.5-4.9$ & 1.95 & 1.73 & 1.12 \\
\hline $5-5.4$ & 2.12 & 1.83 & 1.15 \\
\hline $5.5-5.9$ & 2.13 & 1.93 & 1.1 \\
\hline Average & $1.78 \pm 0.41$ & $1.59 \pm 0.27$ & $1.11 \pm 0.13$ \\
\hline
\end{tabular}

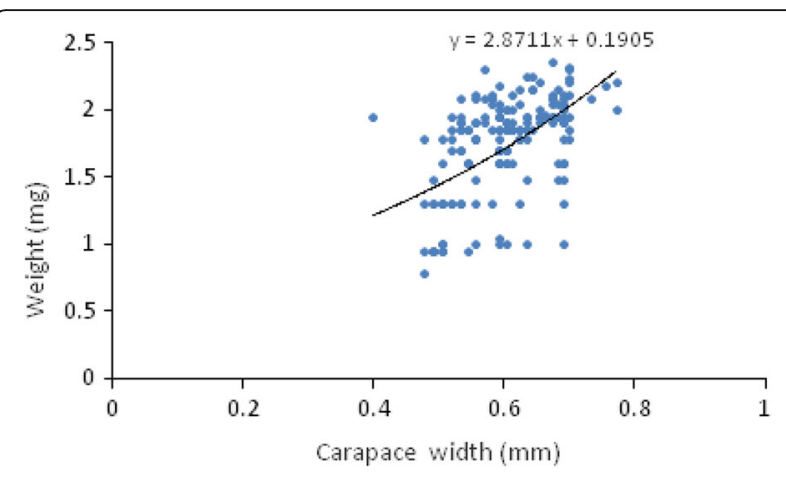

Fig. 2 The width-observed weight relationship of $H$. marsupialis females

lengthy definite breeding season and carries eggs throughout the year. The percentages of ovigorous females recorded 100\% during December decline to the lowest value (57.14\%) during October (Table 2 and Fig. 5). Immature ovaries were translucent, difficult to see, and had very small ova (diameter $0.1 \mathrm{~mm}$ ). Developing ovaries were pale cream or yellow, had a mean ova diameter of $0.32 \mathrm{~mm}$, and ranged between 0.2 and $0.5 \mathrm{~mm}$. Mature ovaries were pale orange with a mean ova diameter of $0.39 \mathrm{~mm}$ and ranged between 0.1 and $0.5 \mathrm{~mm}$. A few specimens with orange ovaries had small ova, but their color was not a fully consistent index of maturity because the median diameter of incubating eggs was around $0.4 \mathrm{~mm}$.

\section{Incubated eggs}

The incubated eggs are semi spherical in shape, with diameter ranges between 10 and $50 \mu \mathrm{m}$ according to maturity stages (Table 3). The color of incubated eggs was varied according to the developmental stage. Color appears pale yellow for newly laid eggs (stage I), and changes as development proceeds to yellow (stage II), bright yellow (stage III), orange (stage IV), and faint orange (stage $\mathrm{V}$ ). It is worth to mention that the smallest females carrying egg were collected throughout May and June (newly laid eggs), and the largest ones were

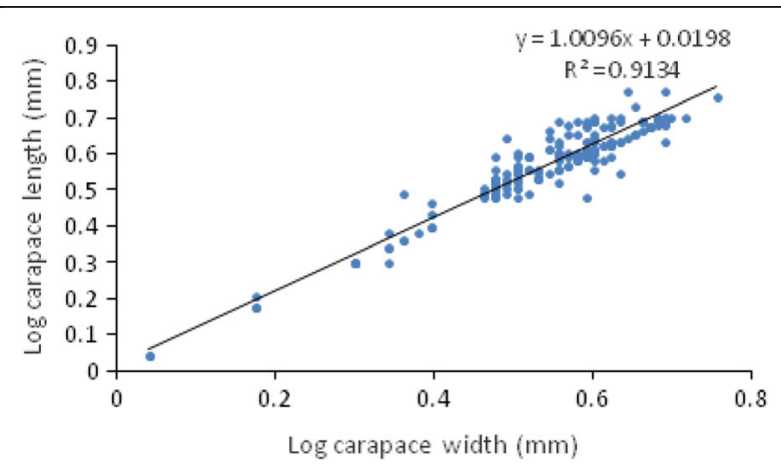

Fig. 3 Carapace width and carapace length relationship of $H$. marsupialis from Gulf of Aqaba, Red Sea, Egypt 


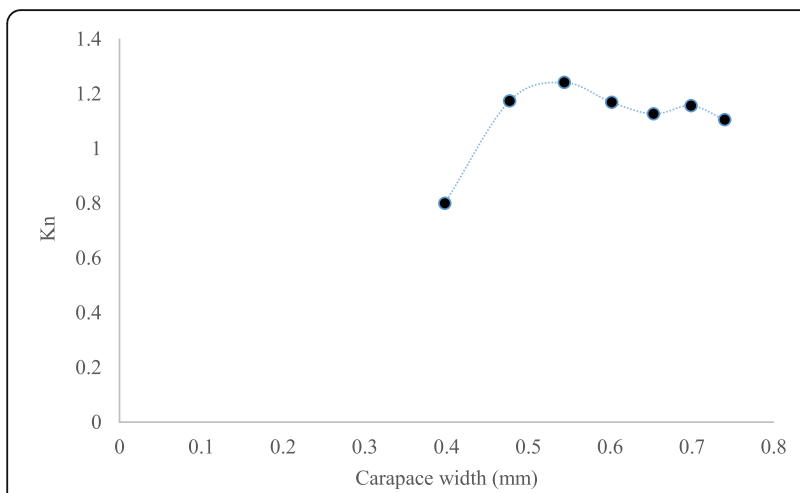

Fig. 4 Relative condition factor of H. marsupialis from Gulf of Aqaba, Red Sea, Egypt

collected throughout June (stage III). However, ovigerous females appeared throughout the year, indicating that the incubation period for this species may extend for 2 months. Ripening ovaries, evidence of mating, and production of eggs all serve as indices of sexual maturity, the production of eggs is an unambiguous sign of functional maturity.

\section{Maturity stages and spawning season}

The onset of smallest ovigerous females was also taken for determining the first maturity size. Field collection showed that the smallest ovigerous female measured $2.4 \times 2.4 \mathrm{~mm}(\mathrm{CW} \times \mathrm{CL})$, captured in June, this means that most females attain sexual maturity between 2 and $2.49 \mathrm{~mm} \mathrm{CW}$ class. Table 2 displays the total number of collected specimens for both maturing females

Table 2 Total number of collected specimens and percentages of ovigerous females and number of juveniles of $H$. marsupialis from Gulf of Aqaba, Red Sea, Egypt

\begin{tabular}{|c|c|c|c|c|c|c|}
\hline \multirow[t]{3}{*}{ Months } & \multicolumn{6}{|l|}{ Number and \% } \\
\hline & \multirow{2}{*}{$\begin{array}{l}\text { Total no. } \\
\text { of specimens }\end{array}$} & \multicolumn{3}{|c|}{ Mature females } & \multirow{2}{*}{$\begin{array}{l}\% \text { of ovig. } \\
\text { females }\end{array}$} & \multirow{2}{*}{$\begin{array}{l}\text { No. of } \\
\text { juveniles }\end{array}$} \\
\hline & & All & Non-Ovig., & Ovig. & & \\
\hline January & 10 & 10 & 1 & 9 & 90 & 0 \\
\hline February & 18 & 14 & 1 & 13 & 92.8 & 4 \\
\hline March & 20 & 15 & 4 & 11 & 73.3 & 5 \\
\hline April & 19 & 14 & 3 & 11 & 78.57 & 5 \\
\hline May & 15 & 14 & 1 & 13 & 92.8 & 1 \\
\hline June & 52 & 35 & 5 & 30 & 85.7 & 17 \\
\hline July & \multicolumn{6}{|c|}{ The area was not visited. } \\
\hline August & 36 & 29 & 4 & 25 & 86.2 & 7 \\
\hline September & 13 & 12 & 2 & 10 & 83.33 & 1 \\
\hline October & 7 & 7 & 3 & 4 & 57.14 & 0 \\
\hline November & 7 & 6 & 1 & 5 & 83.3 & 1 \\
\hline December & 10 & 9 & 0 & 9 & 100 & 1 \\
\hline Total & 207 & 165 & 25 & 140 & 84.85 & 42 \\
\hline
\end{tabular}

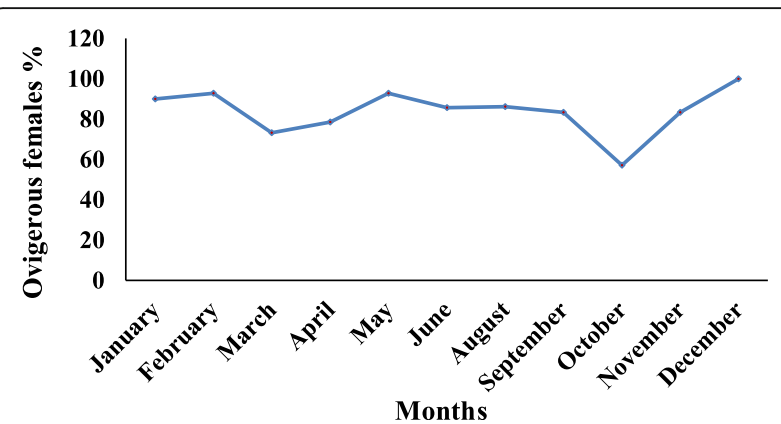

Fig. 5 Monthly percentages of $H$. marsupialis ovigerous females showing spawning season from Gulf of Aqaba, Red Sea, Egypt

(ovigerous) and juveniles of $H$. marsupialis. The percentage of mature females is $79.7 \%$, while juveniles are $20.3 \%$ recorded in all months except January and October. The lowest value of juveniles was 1 recorded during May, September, November, and December, and the highest value was 17 recorded in June (Fig. 6). These results denote to the relatively short period for juvenile metamorphosis after hatching and to the short breeding season for this species.

\section{Fecundity}

The incubated eggs for $140 \mathrm{H}$. marsupialis females were counted. The egg number (fecundity) of these females was relatively low, varying from 10 to 740 , with an average of $230.3 \pm 172.8$ eggs /female. The smallest ovigerous female was $2.4 \times 2.4 \mathrm{~mm}(\mathrm{CW} \times \mathrm{CL})$, collected in June, carrying 150 eggs, all at stage (II), while the largest egg number was 740 , at stage (IV), with size $4.0 \times 3.6 \mathrm{~mm}$ $(\mathrm{CW} \times \mathrm{CL})$ collected also in June; whereas the lowest egg number was 10 for sizes of $3.1 \times 3.1 \mathrm{~mm}, 3.2 \times$

Table 3 Maturity stages of $H$. marsupialis ovigerous females from Gulf of Aqaba, Red Sea, Egypt

\begin{tabular}{lllllll}
\hline Months & \multicolumn{5}{l}{ Stages } & \multicolumn{1}{l}{} \\
\cline { 2 - 7 } & I & II & II & IV & V & Diameter of oocytes $(\mu \mathrm{m})$ \\
\hline January & 3 & 2 & 1 & 3 & & $20-49$ \\
February & 6 & 3 & & 2 & 2 & $10-45$ \\
March & 6 & 1 & 4 & & & $35-50$ \\
April & 4 & 4 & 3 & & & $31-50$ \\
May & 5 & 2 & 3 & 1 & 2 & $30-49$ \\
June & 8 & 10 & 5 & 7 & & $30-47$ \\
July & The area was not visited. & \\
August & 3 & 9 & 7 & 3 & 3 & $21-45$ \\
September & 1 & 4 & 2 & 1 & 2 & $32-50$ \\
October & 1 & 2 & & 1 & & $23-50$ \\
November & 3 & 1 & & 1 & & $22-48$ \\
December & 5 & 2 & 1 & 1 & & $31-45$
\end{tabular}




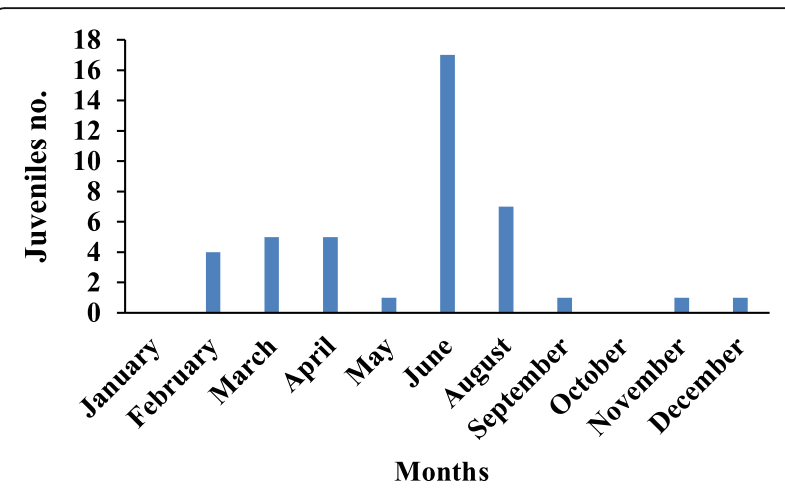

Fig. 6 Monthly juvenile recruitment variations of H. marsupialis from Gulf of Aqaba, Red Sea, Egypt

$3.0 \mathrm{~mm}, 4 \times 3.9$, and $3.9 \times 3.3 \mathrm{~mm}(\mathrm{CW} \times \mathrm{CL})$, collected in May, June, and February respectively.

The logarithmic relationship between carapace width and total egg number or fecundity $(F)$ was illustrated in Fig. 7 and represented by the following equation:

$$
\log F=0.22+2.39 \log \mathrm{CW}
$$

This relation is statistically significant, showing linear relation with low correlation coefficient " $r$ " being 0.76 , and negative allometric regression coefficient " $b$ " $=(2.39)(b<3$, $P<0.05)$ with positive intercept of $Y$-axis, " $a "=0.22$. The prevalence of maturity increased with size.

\section{Discussion}

The current study is considered the first investigation about biology of the coral gall crab, $H$. marsupialis at Egyptian coast of Gulf of Aqaba. However, Mohammed and Yassien (2013) studied the distribution of H. marsupialis along the Red Sea coast while Kotb and Hartnoll (2002) studied the biology of the coral gall crab H. marsupialis at South of Hurghad. On the other hand, the

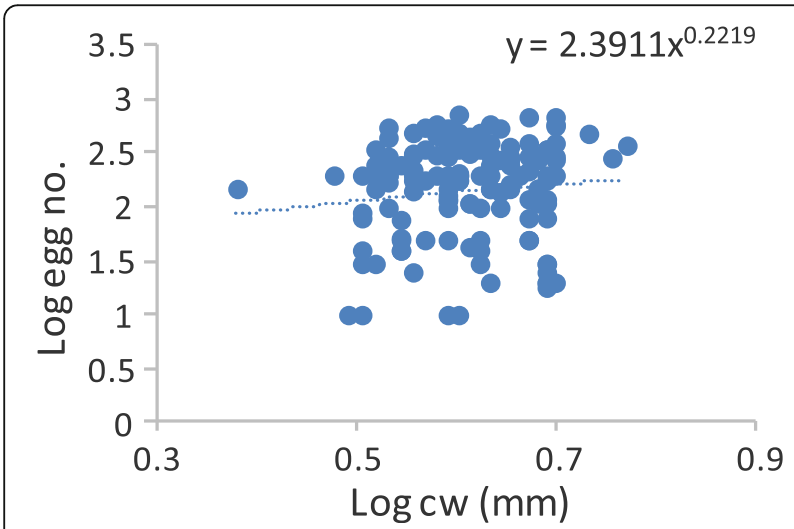

Fig. 7 The logarithmic relationship between carapace width and total egg number of H. marsupials from Gulf of Aqaba, Red Sea, Egypt reproductive biology of true crabs along the Egyptian coast of the Red Sea and Gulfs of Suez and Aqaba were well documented in several studies (El-Sayed, 1997, 2004; El-Sayed, Saber, El-Damhougy, \& Fouda, 1998, El-Sayed, Fouda, Azab, \& Ismail, 2011, El-Sayed et al., 2014; Fouda, 2000). During the present investigation, $H$. marsupialis were recorded hosted to Stylophora pistillata. This finding was concurrent with Fize and Serene (1957) and Mohammed and Yassien (2013).

In the present study, the relationships between carapace width and weight of $H$. marsupialis showed negative allometry $(b=2.87)$. Bagenal and Tesch (1978) mentioned a similar result that the isometric growth rate ( $b$ value) is ranged from 2.5 to 3.5 , while an increase or decrease of " $b$ " value than that range indicates allometric negative growth $(b$ value $<2.5)$ or positive growth $(b$ value > 3.5). However, Du-Preez and Mclachlan (1984) found isometric positive relationships between carapace width and body weight of Portunus pelagicus and Ovalipes punctatus. The increments in carapace width than weight for $H$. marsupials may be attributed to either environmental or biological factors particularly availability of food and breeding seasons (El-Sayed, 1997, 2004; Abd El-Razek, 2006; Josileen, 2011; Thirunavukkarasu \& Shanmugam, 2011; Aydin, 2013).

The isometric growth rate was calculated between carapace width and carapace length (regression coefficient; $b=1.009$ ); this agrees with Kotb and Hartnoll (2002) on H. marsupialis. Hartnoll (1982) clarified that if the regression coefficient $(b)$, which defines the type of allometric growth rates, exceeds 1 , it gives positive allometry, if equals 1 referring to the isometry, but if it is less than 1 indicating negative allometry. Du-Preez and Mclachlan (1984) recorded a positive allometric growth rate between these two variables for Ovalipes punctatus, while slight negative allometry in Telmessus cheiragonus and T. acutidens was recorded by Urita (1936).

The results of relative condition factor "kn" for the whole populations of $H$. marsupials females were varied from 0.8 to 1.24 and averaged $1.11 \pm 0.13$. This result agrees with the finding of El-Sayed et al. (2011) on Petrolisthes rufescens, Arab (2010) on P. marmoratus and P. transversus, Salem (2014) on Trapezia cymodoce, and Salem, Fouda, Al-Hammady, and El-Damhougy (2017) on Tetralia glaberrima. The values of kn denote a well-being or fitness for whole population and measure the well-being of crabs depending upon the relationship between carapace width and total body weight. Similar results were recorded by El-Sayed (1992) on L. signata and E. crenata, Fouda (2000) on L. exarartus and M. messor, El-Sayed (2004) on L. exarartus, and Salem (2014) on T. cymodoce from the Red Sea.

There is a clear external morphological sexual dimorphism for $H$. marsupialis females, characterized by 
broad abdomens and provided with four pairs of segmented biramous pleopods, while males have an elongated tapering abdomen and two pairs of uniramus pleopods. This is in agreement with the results carried out on other brachyurans (Hartnoll, 1974 and Hartnoll, 1982; Abd El-Razek, 1987; El-Sayed, 1997 and El-Sayed, 2004; De Lasting, Hall, \& Potter, 2003; El-Sayed et al., 2011 and El-Sayed et al., 2014 and Salem, 2014). Like most Red Sea brachyuran crabs, H. marsupials females carry eggs throughout the year; this agrees with Kotb and Hartnoll (2002). The frequencies of berried (gravid) or ovigorous of these females increased gradually, reached its maximum during December. These results agree with Edwards and Emberton (1980), Wolodarsky and Loya (1980), Gotelli, Gilchrist, and Abele (1985), Costa (2000), and El-Sayed et al. (2014), but in disagreement with Erkan, Balkis, Kurun, and Tunali (2008) who mentioned that reproduction of E. verrucosa is correlated with the changes in seawater temperature. However, the fluctuations in the percentage of appearance of ovigerous females may be attributed to the prevailing environmental fluctuations as recorded in the Red Sea (Edwards, 1987; Morcos, 1990; Hamed \& Said, 2000) or to the availability of food (Fusaro, 1978; Fouda, 2000).

The color of incubated eggs is varied according to the developmental stage. Color appears pale yellow for newly laid eggs (stage I), changing, as development proceeds, to yellow (stage II), bright yellow (stage III), orange (stage IV), and faint orange (stage V). This result confirms the finding of El-Sayed et al. (2014) on $T$. cymodoce from the Gulf of Aqaba they reported that egg size shows a gradual decrease towards the late developmental stages, with remarkable change in color, appears pale yellow for newly laid eggs (stage I), and changes as development proceeds to yellow (stage II), bright yellow (stage III), orange (stage IV), and faint orange (stage V). Guillory and Hein (1997) mentioned that the color change is caused by absorption of the yellow yolk and development of dark pigment in the eggs and on the body of the embryos. Size of incubated eggs of $H$. marsupialis is relatively small, and these eggs decrease remarkably and varied between 10 and $50 \mu \mathrm{m}$ in diameter. These measurements are nearly similar to that measured by Arab (2010) that was $(33.6 \mu \mathrm{m})$ in $P$. marmoratus and $(27.5 \mu \mathrm{m})$ in P. transversus, Kotb and Hartnoll (2002) on H. marsupialis $(0.39 \mathrm{~mm})$ at the Red Sea. However, Erkan et al. (2008) found different measurements of egg diameter of E. verrucosa $(610 \mu \mathrm{m})$ at Black Sea and El-Sayed et al. (2014) on T. cymodoce $(131 \mu \mathrm{m})$ from the Gulf of Aqaba.

Eggs at different development stages were detected attached to the receptacle of the pleopods of ovegrious females at the same time. Guillory, Prejean, Bourgeois, Burdon, and Merrell (1996) found that fertilized eggs pass through the spermathecae and then attached to the receptacle of the pleopods. The stages of maturation for the incubated eggs in the present study are similar to those described by Guillory and Hein (1997), El-Sayed (2004) on xanthid crab, L. exaratus, and El-Sayed et al. (2011) on the flattened porcelain crab, Petrolisthes rufescens, from the Red Sea.

$H$. marsupialis females attain sexual maturity between 2 and $2.49 \mathrm{~mm} \mathrm{CW}$ class; these measurements agree with Kotb and Hartnoll (2002).The appearance of ovigerous females in determination of breeding seasons has been employed by several workers. Varadarajan and Subramoniam (1982) used ovigerous females for studying the breeding of the tropical hermit crab, Clibanarius clibanarius. Lancaster (1990) used the frequencies of ovigerous females in demarcation breeding season of the hermit crab, Pagurus bernhardus. The presence of $H$. marsupialis ovigerous females with different developmental incubated egg stages throughout the year may indicate frequency of spawning during the same breeding season. Also, it may define the length of incubation period, which may be up to 1 month (ElSayed et al., 1998; Fouda, 2000; El-Sayed, 1997, 2004; Kotb \& Hartnoll, 2002).

$H$. marsupialis juveniles were recorded during the year except the months of January and October. These results denote relative short period for juvenile metamorphosis after hatching and short breeding season for this species. These agree with Fize (1956), who reported that incubation period is 28 days, while other studies showed that there is a long duration for eggs of $0.4 \mathrm{~mm}$ diameter at a temperature around $25{ }^{\circ} \mathrm{C}$ a duration of 15 days or less is typical (Hartnoll, 1965; Warner, 1967; Wear, 1974). Overall, $80 \%$ of crabs $>3 \mathrm{~mm} \mathrm{CW}$ were ovigerous, indicating that the period between successive incubations averaged about a quarter of the incubation period.

The fecundity of $H$. marsupialis was relatively low. These values are very close to the results of $T$. cymodoce (Salem, 2014) and to H. marsupialis (Kotb \& Hartnoll, 2002) but very low compared with those obtained by Arab (2010) on P. marmoratus from the eastern Mediterranean. The present results showed a decline of relative fecundity with increasing body mass. Hines (1982) reported such a decline for 12 out of 20 species analyzed. There are possible explanations in Hapalocarcinus for this reduction in relative fecundity. One is increasingly poor fertilization success as the sperm is depleted-this has been demonstrated in Chionoecetes (Sainte-Marie \& Carriere, 1995). The second is the limitation of food supply via the small pores in the gall as the crab increase in size and energy requirement (Hines, 1982). It is worth to mention that few eggs' number may be attributed to either egg loss, releasing larvae at the late stages or to beginning of spawning of new egg lay. Such as in most crustaceans and other 
animals, the reproductive investment was highly variable and varied with body size. Large decapods can produce 100,000 eggs in a single clutch (Hartnoll, 2006), whereas the small-sized crustaceans have up to about 100 eggs (Sainte-Marie, 1991). The number of eggs produced was highly correlated with the size of females and was increased with increase in female's size (Preston, 1973, Gotelli et al., 1985; El-Sayed, 1997, 2004; El-Sayed et al., 1998, El-Sayed et al., 2011; Fouda, 2000; and Aydin, 2013).

The linear relationship between fecundity (egg number) and carapace width was evident (allometric regression coefficient; $b=2.39$ ). This result could be explained by the fact that crab size increased faster than egg number. This result agrees with that reported by several authors (Haynes et al., 1976; Atrill \& Hartnoll, 1991; El-Sayed, 1992, 1997, 2004; Siddiqui \& Ahmed, 1992; El-Sayed et al., 1998, El-Sayed et al., 2014; Fouda, 2000; Kotb \& Hartnoll, 2002; and El-Sayed et al., 2011) on several crab species. However, a contrast results were recorded by Gotelli et al. (1985).

\section{Conclusions}

In conclusion, this study was performed to investigate the growth and reproductive biology of the coral gall crab, Hapalocarcinus marsupialis, at Gulf of Aqaba, Red Sea, Egypt. Growth generally shows negative allometric growth. The overall value for "kn" denotes fitness for females. $H$. marsupialis has lengthy definite breeding season and carries eggs throughout the year.

\section{Acknowledgements}

The authors are deeply thankful to the Environmental Egyptian Affairs Agency members, Red Sea Protectorates Sector and members of Zoology Department Al-Azhar University, Nasr City, Cairo, Egypt, for unlimited the support. (We would like to thank Dr. Awaad A.M. EL-Sayed Prof. of marine invertebrates for his support and identification of specimens of this work).

\section{Funding}

No funding

\begin{abstract}
Authors' contributions
KAE is the main investigator responsible for the points of research and revision of manuscript. ESES is the principle investigator of the research work, who is responsible for the field study, lab work, and writing of the manuscript. MMAF is the main investigator who participated in the lab work and writing and revision of the manuscript. MAMMA-H is the main investigator responsible for the field study, identification of specimens, and writing and revision of the manuscript. All authors read and approved the final manuscript.
\end{abstract}

\section{Ethics approval and consent to participate}

Not applicable

\section{Consent for publication}

Not applicable

\section{Competing interests}

The authors declare that they have no competing interests.

\section{Publisher's Note}

Springer Nature remains neutral with regard to jurisdictional claims in published maps and institutional affiliations.

\section{Author details}

${ }^{1}$ Faculty of Science, Al-Azhar University, Nasr City, Cairo, Egypt. ${ }^{2}$ Red Sea Protectorates Sector, Environmental Egyptian Affairs Agency, Cairo, Egypt. ${ }^{3}$ Faculty of Science, Al-Azhar University, Assuit, Egypt. ${ }^{4}$ National Institute of Oceanography and Fisheries, Red Sea Branch, Hurghada, Egypt.

Received: 25 May 2017 Accepted: 23 November 2017

Published online: 18 January 2018

\section{References}

Abd El-Razek, F. A. (1987). Some biological studies on the Egyptian crab Portunus pelagicus (L.) Proc. Zool. Soc. A. R Egypt, 14, 223-233.

Abd El-Razek, F. A. (2006). Population biology of the edible crab, Portunus pelagicus (Linnaeus.) from Bardawil Lagoon, Northern Sinai, Egypt. Egyptian Journal of Aquatic Research, 32, 401-418.

Abele, L. G. (1984). Biogeography, colonization and experimental structure of coral-associated crustaceans. In D. R. Strong, D. Simberloff, L. G. Abele, \& A. B. Thistle (Eds.), Ecological communities: Conceptual issues and the evidence, (pp. 123-137). Princeton: Princeton University Press.

Arab, A. S. (2010). Population structure and biology of Lebanese rocky shore crabs Pachygrabsus marmoratus and P. transversus (Grabsidae), M.Sc. Thesis (). Lebanon: Fac. of Arts and Science at the American University of Beirut.

Atrill, M. J., \& Hartnoll, R. G. (1991). Aspects of the biology of the deep-sea crab, Geryon trispinosus from the Porcupine Seabight. Journal of the Marine Biological Association of the United Kingdom, 71, 311-328.

Aydin, M. (2013). Length-weight relationship and reproductive features of the Mediterranean green crab, Carcinus aestuarii Nardo, 1847 (Decapoda: Brachyura) in the eastern Black Sea, Turkey. Pakistan Journal of Zoology, 45(6), 1615-1622.

Bagenal, T. B., \& Tesch, F. W. (1978). Age and growth. In W. E. Ricker (Ed.), Methods for assessment of fish production in fresh waters, (pp. 101-136). Oxoford and Edinburgh: Blackwell.

Becker, C. (2010). European pea crabs-Taxonomy, morphology, and hostecology (crustacea: brachyura: pinnotheridae) (dissertation), (180 p). Germany: Goethe-University.

Brown, R. B., \& Powell, G. C. (1972). Size at maturity in the male Alaskan Tanner crab, Chionoecetes bairdi as determined by chela allometry, reproductive tract weight and size of procopulatory males. Journal of the Fisheries Research Board of Canada, 29(4), 423-427.

Castro, P. (1976). Brachyuran crabs symbiotic with scleractinian corals: A review of their biology. Mcronesica, 12, 99-110

Chacur, M. M., \& Negreiros-Fransozo, M. L. (2001). Spatial and seasonal distribution of Callinectes danae (Decapoda, Portunidae) in Ubatuba Bay, São Paulo, Brazil. Journal of Crustacean Biology, 21, 414-425.

Choy, S. C. (1985). A rapid method for removing and counting eggs from fresh and preserved decapod crustaceans. Aquaculture, 48, 369-372.

Choy, S. C. (1988). Reproductive biology of Liocarcinus puber and L. holsatus (Decapoda, Brachyura, Portunidae) from the Gower Peninsula, South Wales. Marine Biology, 9, 227-241.

Colpo, K. D., \& Negreiros-Fransozo, M. L. (2003). Reproductive output of Uca vocator (Herbst, 1804) from three subtropical mangroves in Brazil. Crustaceana, 76, 1-11

Conan, G. Y., \& Comeau, M. (1986). Functional maturity and terminal molt of male snow crab Chionoecetes opilio. Canadian Journal of Fisheries and Aquatic Sciences, 43, 1710-1719.

Costa, T. M. (2000). Ecologia de caranguejos semiterrestres do genero Uca (Crustacea, Decapoda, Ocypodidae) deuma area de manguezal, em Ubatuba (SP), Ph.D. thesis (). Brazil: Universidade Estadual Paulista.

De Lasting, S., Hall, N., \& Potter, I. C. (2003). Influence of a deep artificial entrance channel on the biological characteristics of the blue swimmer crab Portunus pelagicus in a large microtidal estuary. Journal of Experimental Marine Biology and Ecology, 295(1), 41-61.

Du-Preez, H. H., \& Mclachlan, A. (1984). Biology of the three spot swimming crab Ovalipes punctatus 2, growth and Moulting. Crustaceana Leiden, 47(2), 13-120.

Edwards, F. J. (1987). Climate and oceanography. In A. Edwards, \& S. M. Head (Eds.), Key environments-Red Sea, (pp. 45-69). Pergamon Press.

Edwards, A., \& Emberton, H. (1980). Crustacea associated with the scleractinian coral, Stylophora pistillata (Esper), in the Sudanese Red Sea. Journal of Experimental Marine Biology and Ecology, 42, 225-240.

El-Sayed, A. A. M. (1992). Biological studies on some brachyuran crabs (Crustaceans) from Suez Canal, Ph. D. Thesis (). Cairo: Zoology Department Faculty of Science, Al- Azhar University. 
El-Sayed, A. A. M. (1997). The biology of spider crab, Menathius monoceros from the Red Sea and Gulf of Aqaba, Egypt. Egyptian Journal of Aquatic Biology and Fisheries, 1(1), 1-16.

El-Sayed, A. A. M. (2004). Some aspects of the ecology and biology of the intertidal xanthid crab, Leptodius exaratus ( $H$. Milne Edwards, 1834) from thre Egyptian Red Sea Coast. Journal of the Egyptian-German Society of Zoology, 45(D), 115-139.

El-Sayed, A. A. M., El-Damhougy, K. A., Hellal, A. M., Salem, M. S. A., Nasef, A. M., \& Salem, S. S. (2014). Reproductive biology of the guard coral crab, Trapezia cymodoce (family Trapeziidae) from Abu Galloum protected area, Gulf of Aqaba, South Sinai, Egypt. Egyptian Journal of Aquatic Biology and Fisheries, 18(2), 89-102.

El-Sayed, A. A. M., Fouda, M. M., Azab, A. M., \& Ismail, M. I. (2011). Reproductive biology of the flattened porcelain crab Petrolisthes rufescens (Porcelanidae: Anomura: Crustacea) from Ain Sukhna, Gulf of Suez, Egypt. Al-Azhar Bulletin of Science, 22(2), 17-32.

El-Sayed, A. A. M., Saber, S. A., El-Damhougy, K. A., \& Fouda, M. M. A. (1998). The reproductive biology of Grapsid crab, Metopograpsus messor (Forskal, 1775) from Ain Sukhna, Gulf of Suez, Egypt. Egyptian Journal of Aquatic Biology and Fisheries, 2(4), 359-377.

Erkan, M., Balkis, H., Kurun, A., \& Tunali, Y. (2008). Seasonal variations in the ovary and testis of Eriphia verrucosa (Forskål, 1775) (Crustacea: Decapoda) from Karaburun, SW Black Sea. Pakistan Journal of Zoology, 40, 217-221.

Fize, A. (1956). Observations biologiques sur les Hapalocarcinides.-Annals Faculte de Science Universite National Viet-Nam. Contributions ION, 22, 1-30.

Fize, A., \& Serene, R. (1957). Les hapalocarcinides du VietNam. Memoirs du Institute Oceanographique de Nhatrang, 10, 1-202.

Flores, A. A. V., Saraiva, J., \& Paula, J. (2002). Sexual maturity, reproductive cycles, and juvenile recruitment of Perisesarma guttatum (Brachyura, Sesarmidae) at Ponta Rasa mangrove swamp, Inhaca Island, Mozambique. Journal of Crustacean Biology, 22, 143-156.

Fontelles-Filho, A. A. (1989). Recursos pesqueiros: biologia e dinâmica populacional, (296 p). Fortaleza: Imprensa Oficial do Ceará.

Fouda, M. M. A. (2000). Biological and ecological studies on some crustacean decapods from the Suez Gulf, M. Sci. Thesis (). Cairo: Zoology Department, Faculty of Science, Azhar University.

Fusaro, G. (1978). Food availability and egg production: A field experiment with Hippa pacifica Dana (Decapoda: Hippidae). Pacific Scientific, 32(1), 17-23.

Gotelli, N. J., Gilchrist, S. L., \& Abele, L. G. (1985). Population biology of Trapezia spp. and other coral-associated decapods. Marine Ecology Progress Series, 21, 89-98.

Guillory, V., \& Hein, S. (1997). Sexual maturity in blue crabs, Callinectes sapidus. Proceedings of the Louisiana. Academy of Sciences, 59, 5-7.

Guillory, V., Prejean, E., Bourgeois, M., Burdon, J., \& Merrell, J. (1996). A biological and fisheries profile of the blue crab, Callinectes sapidus. LA Department of Wildlife and Fisheries Management Plan Series, 8(1), $210 \mathrm{pp}$

Hamed, M. A., \& Said, T. O. (2000). Effect of pollution on the water quality of the Gulf of Suez. Egyptian Journal of Aquatic Biology and Fisheries, 4(1), 161-178.

Hartnoll, R. G. (1965). The biology of spider crabs: A comparison of British and Jamaican species. Crustaceana, 9, 1-16.

Hartnoll, R. G. (1974). Variation in growth pattern between some secondary sexual characters in crabs (Decapoda: Brachyura). Crustaceana, 27(2), 131-136.

Hartnoll, R. G. (1982). Growth. In L. G. Abele (Ed.), The biology of Crustacea, 2. Embryology, morphology, and genetics, (pp. 111-197). New York: Academic Press.

Hartnoll, R. G. (2006). Reproductive investment in Brachyura. Hydrobiologia, 557, 31-40.

Haynes, E., Karinen, J. F., Watson, J., \& Hopson, D. J. (1976). Relation of number of egg and egg length to carapace width in the brachyuran crabs Chionoecetes bairdi and C. opelio from the south eastern Bering Sea and C. opilio from the Gulf of St. Lawrence. Journal of the Fisheries Research Board of Canada, 33, 2592-2595

Hile, R., 1936. Age and growth of the Ciscoe leveichthys artedi (Le sueur.), in The lakes of the northeastern high lands, Wisconsin. Bulletin of Marine Fishes U.S. 48 (19) 211-317.

Hines, A. H. (1982). Allometric constraints and variables of reproductive effort in brachyuran crabs. Marine Biology, 69, 309-320.

Josileen, J. (2011). Food and feeding of the blue swimming crab, Portunus pelagicus (Linnaeus, 1758) (Decapoda, Brachyura) along the coast of Mandapam, Tamil Nadu, India. Crustaceana, 84(10), 1169-1180.

Kotb, M. M., \& Hartnoll, R. G. (2002). Aspects of the growth and reproduction of the coral gall crab Hapalocarcinus marsupialis. Journal of Crustacean Biology, 22(3), 558-566.
Kropp, R. K. (1990). Revision of the genera of gall crabs (Crustacea: Cryptochiridae) occurring in the Pacific Ocean. Pacific Science, 44, 417-448.

Lancaster, I. (1990). Reproduction and life history strategy of the hermit crab Pagurus bernhardus. Journal of the Marine Biological Association of the United Kingdom, 70, 129-142.

Le Cren, C. D. (1951). The length-weight relationship and seasonal cycle in gonad weights and condition in the perch (Percafluviatilis). Journal of Animal Ecology, 20, 201-219.

López-Greco, L. S., Hernandez, J. E. J., Bolanos, J., Rodriguez, E. M., \& Hernandez, G. (2000). Population features of Microphrys bicornutus Latreille, 1825 (Brachyura, Majidae) from Isla Margarita, Venezuela. Hydrobiologia, 439, 151-159.

McCain, J. C., \& Coles, S. L. (1979). A new species of crab (brachyura, hapalocarcinidae) inhabiting pocilloporid corals in Hawaii. Crustaceana, $36,81-89$

Mohammed, T. A. A., \& Yassien, M. H. (2013). Assemblages of two gall crabs within coral species Northern Red Sea, Egypt. Asian Journal of Scientific Research, 6(1), 98-106.

Morcos, S. A., 1990. Physical and chemical oceanography. In S. A. Morcos, \& A. Varly (Eds.), Red Sea, gulf of Aden and Suez Canal. A bibliography on oceanographic and marine environmental research, (pp. xvi-xxii) UNESCO.

Mouton, E. C. J. R., \& Felder, D. L. (1995). Reproduction of the fiddler crabs Uca longisignalis and Uca spinicarpa in a Gulf of Mexico salt marsh. Estuaries, 18, 469-481.

Murai, M., Goshima, S., \& Henmy, Y. (1987). Analysis of the mating system of the fiddler crab Uca lactea. Animal Behavior, London, 35, 1334-1342.

Negreiros-Fransozo, M. L., Fransozo, A., \& Bertini, G. (2002). Reproductive cycle and recruitment period of Ocypode quadrata (Decapoda: Ocypodidae) at a sandy beach in southeastern Brazil. Journal of Crustacean Biology, 22, 157-161.

Patton, W. K. (1974). Community structure among the animals inhabiting the coral Pocillopora damicornis at Heron Island, Australia. In W. B. Vernberg (Ed.), Symbiosis in the sea, (pp. 219-243). Columbia: University of South Carolina Press.

Pillay, K. K., \& Nair, N. B. M. (1971). The annual reproductive cycles of Uca annulipes, Portunus pelagicus and Metapenaeus affins (Decapoda, Crustacea) from the South-west of coast. Journal of the Marine Biological Association of India, 11, 152-166.

Preston, E. M. (1973). A computer simulation of competition among five sympatric congeneric species of xanthid crabs. Ecology, 54, 469-483.

Rodríguez, A., Drake, P., \& Arias, A. M. (1997). Reproductive periods and larval abundance patterns of the crabs Panopeus africanus and Uca tangeri in a shallow inlet (SW Spain). Marine Ecology Progress Series., 149, 133-142.

Sainte-Marie, B. (1991). A review of the reproductive bionomics of aquatic gammaridean amphipods: Variation of life history traits with latitude, depth, salinity and superfamily. Hydrobiologia, 223, 189-122.

Sainte-Marie, B., \& Carriere, C. (1995). Fertilisation of the second clutch of eggs of snow crab, Chionoecetes opilio, from females mated once or twice after their molt to maturity. Fisheries Bulletin (U.S.), 93, 759-764.

Salem, S. (2014). Biological studies on some marine invertebrates and their relation with coral reefs at Abu Galum protected area, Gulf of Aqba, South Sini, Egypt, M.Sc. Thesis (). Cairo: Marine Biology, Faculty of Science, Al-Azhar University.

Salem, S. S., Fouda, M. M., Al-Hammady, M. A., \& El-Damhougy, K. A. (2017). Biometric relationships and condition factor of Tetralia glaberrima Herbst, 1790, gulf of Aqaba, Red Sea, Egypt. International Journal of Fisheries and Aquatic Studies 2017, 5(2), 691-698.

Serene, R. (1962). Species of Cryptochirus of Edmondson 1933 (Hapalocarcinidae). Pacific Scientific, 16, 30-41 fig. 15.

Serene, R. (1966). Note sur la taxonomie et la distribution geographique des Hapalocarcinidae (Decapoda Brachyura). Proc. Symp. Crustacea, Ernakulam. Journal of the Marine Biological Association of India, 1965, Part 1, 395-398.

Siddiqui, G., \& Ahmed, M. (1992). Fecundities of some marine brachyuran crabs from Karachi (Pakistan). Pakistan Journal of Zoology, 24(1), 43-45.

Somerton, D. (1980a). A computer technique for estimating the size of sexual maturity in crabs. Canadian Journal of Fisheries and Aquatic Sciences, 37, 1488-1494.

Somerton, D. (1980b). Fitting straight lines to Hiatt growth diagrams: A reevaluation. Journal du Conseil / Conseil Permanent International pour l'Exploration de la Mer, 39, 15-19.

Stimpson, W. (1859). Hapalocarcinus marsupialis, a remarkable new form of brachyurous crustacean on the coral reefs of Hawaii. Proceedings of the Boston Society of Natural History, 6, 412-413.

Subramoniam, T. (1982). Determination of reproductive periodicity in the intertidal mole crab, Emerita asiatica. In T. Subramoniam (Ed.), Manual of 
research methods for marine invertebrates and reproduction, (pp. 163-167). Cochin: CMFRI Publication, No.9.

Thirunavukkarasu, N., \& Shanmugam, A. (2011). Length-weight and width-weight relationships of mud crab Scylla tranquebarica (Fabricius, 1798). Journal of Marine Biological Association of India, 53(1), 142-144.

Urita, T. (1936). Dimentional, morphological and zoogeographical study of Japanese crabs of the genus Telmessus. Sci. Rep. Tohoku Imp. Univ. Sendai, Ser.4, 11, 69-89 7 fig. USA. Journal of Shellfish Research 3 (2): 117-128.

Varadarajan, S., \& Subramoniam, T. (1982). Reproduction of the continuous breeding tropical hermit crab, Clibanarius clibanarius. Marine Ecology Progress Series, 8, 197-201.

Vehof, J., Van der Meij, S. E. T., Türkay, M., \& Becker, C. (2014). Female reproductive morphology of coral-inhabiting gall crabs (crustacea: decapoda: brachyura: cryptochiridae). Acta Zoologica Stockholm, 97(1), 117-126.

Verrill, A. E. (1867). Remarkable instances of crustacean parasitism. American Journal of Science, 44(2), 126.

Warner, G. F. (1967). The life history of the mangrove tree crab, Aratus pisoni. Journal of Zoology, 153, 321-335.

Warner, G. F. (1977). The biology of crustacea. London: Elek Science.

Watson, J. (1970). Maturity, mating and egg laying in the spider crab, Chionoecetes opilio. Journal of the Fisheries Research Board of Canada, 27, 1607-1616

Wear, R. G. (1974). Incubation in British decapod Crustacea, and the effects of temperature on the rate and success of embryonic development. Journal of the Marine Biological Association of the United Kingdom, 54, 745-762.

Wei, T. P., Hwang, J. S., Tsai, M. L., \& Fang, L. S. (2006). New records of gall crabs (Decapoda, Cryptochiridae) from Orchid Island, Taiwan, northwestern Pacific. Crustaceana, 78(9), 1063-1077.

Wolodarsky, Z., \& Loya, Y. (1980). Population dynamics of Trpezia crabs inhabiting the coral Styllophora pistillata in the north Gulf of Aqaba. Israel Journal of Zoology, 29, 204-205 (Abstract).

\section{Submit your manuscript to a SpringerOpen ${ }^{\odot}$ journal and benefit from:}

- Convenient online submission

- Rigorous peer review

- Open access: articles freely available online

- High visibility within the field

- Retaining the copyright to your article

Submit your next manuscript at $\gg$ springeropen.com 